\title{
ARRECADAÇÃO TRIBUTÁRIA MUNICIPAL EM TEMPOS DE CRISE - POSSIBILIDADES
}

\author{
City tax revenue in times of crisis - possibilities
}

\section{Isabella Vieira do Nascimento}

Procuradora do Município de Campinas, SP, Brasil. Graduada em Direito pela Universidade Federal Fluminense. Pós-graduada em Direito Tributário pela Universidade Cândido Mendes (RJ).

\section{Maira Neurauter}

Mestre em Direito Constitucional pelo Programa da Pós Graduação em Direito Constitucional da Universidade Federal Fluminense, Brasil. Pós Graduada em Direito Administrativo pela Universidade Cândido Mendes. Bacharel em Direito pela Universidade Federal Fluminense.

\begin{abstract}
Resumo
O presente artigo busca, por método jurídico-dogmático, identificar quais são os institutos do Direito Tributário teoricamente mais úteis para imprimir eficiência à arrecadação tributária em um contexto de recessão econômica mundial, queda de receitas e aumento dos gastos públicos relacionados à crise decorrente da pandemia da Covid19. A partir da análise das possibilidades de aplicação de institutos como parcelamento, moratória, transação e dação em pagamento, foram investigadas quais medidas fiscais foram postas em prática pelos municípios brasileiros durante a crise. A pesquisa constatou que as medidas adotadas foram mais de caráter extrafiscal, voltadas à ajuda socioeconômica do contribuinte do que a assegurar os níveis de arrecadação, embora não se descarte a efetiva aplicação dos instrumentos tributários analisados em um futuro próximo, quando a necessidade municipal de obtenção de receita pode vir a se intensificar.
\end{abstract}

Palavras-chave: Arrecadação tributária. Municípios. Recessão econômica. Medidas fiscais. Medidas socioeconômicas.

\begin{abstract}
This article seeks, by a legal-dogmatic method, to identify which are the Tax Law institutes that are more useful to bring efficiency to tax revenues in a context of global economic recession, falling revenues and increased public spending related to the crisis resulting from the pandemic from Covid19. Based on the analysis of the possibilities of applying institutes such as installments, moratorium, transactions and payment in kind, it was investigated which fiscal measures were put in place by Brazilian cities during the crisis. The survey found that the measures adopted were more of an extra-fiscal nature, aimed at the taxpayer's socioeconomic assistance than at ensuring collection levels, although the effective application of the tax instruments analyzed in the near future is not discarded, when the municipal need to obtain revenue may intensify.
\end{abstract}

Keywords: Tax revenue. City. Economic recession. Fiscal measure. Socioeconomic measure.

\section{Sumário}

1. Introdução; 2. Medidas fiscais em tempos de crise; 2.1 Moratória; 2.2 Parcelamento; 2.3 Transação; 2.4. Dação em pagamento; 3. Medidas adotadas pelos municípios; 4. Conclusão; 5. Notas; Referências. 


\section{INTRODUÇÃO}

O mundo que existiu até o ano de 2019 não existe mais. Todos estamos tendo que nos adaptar a essa nova realidade imposta pela pandemia do vírus SARSCOV2, que implica tanto na proteção da saúde e da vida da população como na preservação do sistema de saúde que, no Brasil, é público e universal (art. 196 da Constituição da República Federativa do Brasil).

Características específicas do vírus, como a fácil transmissibilidade e a possibilidade de evolução da doença para complicações graves em algumas pessoas, inclusive com risco de óbito, forçaram uma mudança brusca na rotina e nos hábitos da população. Consequentemente, refletiram na saúde econômica do país.

O grande número de pessoas doentes, a insegurança sobre o futuro, as medidas de isolamento social, são fatores que contribuem para a queda na atividade econômica, tanto no aspecto da demanda como no aspecto da oferta, gerando reflexos nos empregos, nos salários, na produção industrial, no consumo, no comércio e na prestação de serviços.

O Fundo Monetário Internacional - FMI tem promovido sucessivas revisões da projeção para o encolhimento do Produto Interno Bruto - PIB brasileiro e mundial. A última projeção que se tem notícia (junho de 2020) é de 9,1\% de encolhimento do PIB nacional e 4,9\% do PIB mundial. Trata-se de um momento de recessão econômica não só no Brasil, mas em todas as regiões do mundo.

A consequência, para o Poder Público, é dramática, especialmente para os Municípios, que, em virtude do desenho constitucional de competências, estão na linha de frente da saúde pública. Eles precisam aumentar os gastos no setor e, ao mesmo tempo, se deparam com uma queda brusca na arrecadação.

Se formos analisar as fontes de receita pública derivada dos Municípios brasileiros, que é o tipo de receita mais afetada por uma crise econômica, nos deparamos tanto com fontes próprias como oriundas de transferências constitucionais.

As fontes próprias são aquelas que a Constituição Federal atribuiu como de competência municipal (art. 145, 149-A e 156 da CRFB): impostos (IPTU, ITBI e ISS); taxas; contribuições de melhoria; e contribuição para custeio do serviço de iluminação pública.

As transferências constitucionais são as porcentagens de participação do Município na arrecadação dos tributos do Estado e da União, definidas na seção de "repartição de receitas tributárias" da Constituição Federal (art. 157 a 162). Em geral, na maioria dos Municípios, exceto capitais e grandes metrópoles, é possível afirmar que as transferências constitucionais constituem a maior parte do orçamento público municipal.

Em resumo, o Município recebe do Estado $25 \%$ do ICMS, 50\% do IPVA e $25 \%$ do IPI que o Estado receber, $25 \%$ da CIDE que o Estado receber; e recebe da União $100 \%$ do IR incidente na fonte sobre rendimentos pagos pelo Município, 50\% do ITR (ou 100\%, se for fiscalizado e cobrado pelo Município), $22,5 \%$ do IR e $22,5 \%$ do IPI, os dois últimos por meio do Fundo de Participação dos Municípios. 
Isso significa que, em um contexto de crise econômica, o Município não é afetado apenas pelo impacto no setor de serviços e imobiliário, como se poderia imaginar pelos impostos de competência municipal. Na verdade, a queda na arrecadação no âmbito federal e estadual produzem reflexos diretos no quantitativo de recursos repassados para o orçamento municipal.

Diante desse cenário, a pergunta que se propõe é se seria possível garantir a arrecadação do Município sem que seja necessário recorrer à oneração do contribuinte, que também está sofrendo com as consequências da crise econômica.

O problema que vai nortear o presente trabalho leva em consideração que nesse contexto de crise sanitária, humanitária e econômica, a criação e a majoração de tributos no âmbito municipal não é uma opção política viável para o reforço do orçamento público.

Para responder tal questionamento, é preciso revisitar institutos de Direito Tributário e processo tributário já consagrados, com o foco na efetividade da recuperação de créditos que já existem e se encontram em fase de cobrança administrativa e judicial.

Portanto, a hipótese do presente estudo tem como ponto de partida a identificação da Dívida Ativa, entendida esta como os créditos tributários e não tributários não adimplidos voluntariamente pelo devedor (art. $2^{\circ}$ da Lei $n^{\circ}$ 6830/80 c/c art. $39 \$ 2^{\circ}$ da Lei 4320/64), como fonte para o reforço do orçamento público municipal, em um contexto de queda na arrecadação.

No que se refere à metodologia, a principal vertente teórico-metodológica a ser adotada será a jurídico-dogmática, pois trabalha com "a avaliação de estruturas internas ao ordenamento jurídico", segundo a definição apresentada por Miracy Gustin e Maria Tereza Fonseca Dias (2006, p. 21). Além disso, será adotada como metodologia de pesquisa, a pesquisa bibliográfica doutrinária, através da consulta e estudo de bibliografia nacional; e a legislativa, através da análise dos atos normativos editados em diferentes Municípios, situados em diversas regiões do país, que previram medidas fiscais diante da situação de calamidade na saúde pública.

No primeiro capítulo será feita uma investigação do tipo jurídico-interpretativo (GUSTIN; DIAS, 2006), em uma perspectiva descritiva de institutos de suspensão e extinção do crédito tributário, porém contextualizada pelo olhar focado na sua instrumentalização para a recuperabilidade efetiva e imediata do crédito. Serão tratados os institutos da moratória, transação, parcelamento e dação em pagamento.

O segundo capítulo será dedicado a um estudo analítico das principais medidas fiscais que efetivamente foram implementadas nos municípios que são capitais de estado. A escolha dos municípios estudados se deu mais por uma questão de ordem prática do que por uma questão metodológica. Infelizmente a transparência dos atos administrativos e legislativos dos Municípios brasileiros não é muito eficiente, de forma que não é tarefa fácil encontrar a publicação oficial de decretos e leis municipais, mesmo em municípios de grande porte.

Assim, optou-se por selecionar os atos normativos de municípios capitais que foram 
publicados com fácil acesso na rede mundial de computadores, garantindo, assim, uma observação mais ampla, em âmbito nacional, de municípios que exercem um papel relevante na dinâmica local. Isso possibilita, pelo método indutivo, a observação de como os entes municipais têm enfrentado a crise.

A partir dessa pesquisa, verificou-se que as medidas estudadas que possuem um caráter de auxílio ao contribuinte foram as que mais tiveram implementação nos municípios analisados. Porém, ainda há espaço para que novas medidas fiscais sejam implementadas, principalmente as que visam combater a crise de caixa e manter a arrecadação municipal.

\section{MEDIDAS FISCAIS EM TEMPOS DE CRISE}

Em março de 2020, após provocação presidencial, o Congresso Nacional decretou estado de calamidade pública com efeitos até 31 de dezembro de 2020, possibilitando o afastamento de algumas exigências ordinárias da Lei de Responsabilidade Fiscal (Lei Complementar $n^{\circ} 101$, de 4 de maio de 2000), como o atingimento das metas fiscais previstas para a União no exercício de 2020 e a limitação de empenho, nos termos do artigo 65 da própria LRF.

Em grande parte, Estados e Municípios também seguiram esse caminho, editando seus próprios decretos de calamidade pública. A medida, vale lembrar, já havia ocorrido no ano de 2016 no âmbito do Estado do Rio de Janeiro, mas em outro contexto. Em situação extrema de suas já combalidas finanças públicas, o ente estadual não resistiu à brusca queda no preço do petróleo, com redução extrema de sua arrecadação de royalties e participações especiais, vindo a declarar "estado de calamidade financeira" por meio do Decreto estadual $n^{\circ} 45.692 / 2016$.

Ainda assim, as flexibilizações orçamentárias autorizadas pelo artigo 65 da LRF não foram suficientes. $\mathrm{O}$ aumento nos gastos com o combate à pandemia e aos seus efeitos econômicos, por um lado, e a queda na arrecadação ocasionada pela desaceleração na economia, por outro, pressionaram o Estado a encontrar novas fontes de receita e/ou formas de compensação para o iminente desequilíbrio que não era apenas orçamentário, mas também financeiro.

Já em março de 2020, a Presidência da República ajuizou a Ação Direta de Inconstitucionalidade (ADI) 6357 requerendo o afastamento de algumas exigências da Lei de Responsabilidade Fiscal (Lei Complementar 101/2000) e da Lei de Diretrizes Orçamentárias federal (Lei 13.898/2020) a fim de possibilitar a renúncia de receita e a criação ou expansão de despesas com programas de combate aos efeitos do novo coronavírus sem a ordinária demonstração de compatibilidade e adequação orçamentária.

O excepcional afastamento da incidência dos artigos 14, 16, 17 e 24 da LRF e 114, caput, e parágrafo 14, da LDO federal para 2020 foi autorizado em sede de medida cautelar, por decisão do Ministro do Supremo Tribunal Federal Alexandre de Moraes, posteriormente referendada pelo Plenário, com efeitos estendidos a todos os entes federativos em estado de calamidade pública.

Posteriormente, pela via legislativa, a edição da Emenda à Constituição $n^{0} 106$, de 7 
de maio de 2020 veio ao encontro da necessidade da União de obter receita. Apelidada de "emenda do orçamento de guerra", a EC 106/2020 instituiu um regime orçamentário e fiscal excepcional para as ações relacionadas ao combate ao coronavírus bem como aos seus efeitos econômicos e sociais.

Além de oficializar o afastamento temporário de algumas exigências da LRF, a Emenda também afastou, durante o estado de calamidade pública nacional, a denominada "regra de ouro" prevista no inciso III do caput do art. 167 da Constituição Federal. Com essa previsão, o Congresso Nacional legitimou a escolha política pela emissão de dívida pública como fonte de financiamento estatal.

De fato, o art. 167, inciso III da CF, ao vedar a contratação de operações de crédito em montante superior às despesas de capital, impedia que o Poder Público realizasse empréstimos, seja com a emissão da dívida interna seja com a externa, para custear despesas correntes, impedimento que deixou de existir para o período previsto na EC 106/2020.

Ocorre que, comparada à União, a situação de Estados e Municípios é particularmente mais delicada porque, embora a Constituição não Ihes tenha vedado a emissão de títulos da dívida pública (ao contrário, o art. 52, inciso IX prevê a competência do Senado Federal para estabelecer limites globais e condições para o montante da dívida mobiliária dos Estados, do Distrito Federal e dos Municípios), desde a edição da Lei Complementar $n^{\circ} 148$ de 25 de novembro de 2014, há vedação legal expressa para tanto, no seu artigo 11. Assim, diferentemente do que ocorre com a União, emitir títulos públicos como forma de angariar recursos não é uma alternativa válida para Estados e Municípios.

Por outro lado, também a Constituição não Ihes outorgou competência para instituírem novas fontes de receita tributária tampouco para emitirem moeda, competências exclusivas da União (artigos 154 e 21, VII da CF/88).

$\mathrm{Na}$ verdade, ainda que fosse possível a Estados e Municípios a instituição de novos tributos de sua competência, a partir de uma concepção "neokeynesiana", essa também não seria a melhor postura estatal em um cenário de recessão econômica. Isso porque a elevação da carga tributária total ocasiona uma transferência de recursos dos particulares para o Estado, o que, em um momento de já acentuada desaceleração da economia e crescimento na taxa de desemprego, agravaria ainda mais a queda no consumo e na demanda, com consequente queda na produção e realimentação do ciclo.

Ao contrário disso, o pensamento capitaneado por John Maynard Keynes pregava a injeção de recursos e estímulos no mercado em momentos de recessão. Sobre o tema, vale transcrever a sintética e didática explicação de Aragão (2018):

Por vezes, para restaurar o equilíbrio do mercado é necessário que o Estado intervenha de maneiras diversas - desde medidas regulatórias ao aumento da participação das empresas estatais no PIB. Esse processo é conhecido, na teoria keynesiana, como atuação anticíclica. O exemplo desse tipo de atuação ocorreu na crise econômica que assolou os Estados Unidos em 2008. O Estado, por meio do FED (Federal Reserve System), injeta capital no sistema, comprando ativos problemáticos dos bancos. PEREIRA, Luiz Carlos Bresser. O caráter cíclico da intervenção estatal, In: Revista de Economia Política, v. 9, n. 3, jul.-set. 1989. Keynes contestava a premissa básica dos economistas liberais clássicos de que o livre mercado gera necessariamente o equilíbrio 


\begin{abstract}
econômico. Para Keynes, o pleno emprego e a plena demanda são verificados quando a propensão a consumir encontra-se vinculada ao incentivo para investir. Em tempos de recessão, o estimulo ao consumo é reduzido e, nesse momento, o Estado deve adotar políticas anticíclicas por meio de intervenção direta e, consequentemente, aumento do déficit público. O principal objetivo dessas politicas anticíclicas seria aumentar a demanda, de modo que o mercado atinja novamente o equilíbrio. KEYNES, John Maynard. A Teoria Geral do Emprego do Juro e da Moeda. São Paulo Nova Cultural Ltda., p. 169-171. (ARAGÃO, 2018, p. 107, grifo nosso).
\end{abstract}

É bem verdade que a União editou medidas voltadas a minimizar os efeitos da queda das receitas estaduais e municipais. Em 2 de abril de 2020, foi editada a Medida Provisória $n^{\circ} 938$, pela qual a União se comprometeu a compensar a variação negativa nos valores de repasses ao Fundo de Participação dos Estados (FPE) e ao Fundo de Participação dos Municípios (FPM) verificadas nos meses de março a junho de 2020, em comparação com o mesmo período de 2019, limitado o apoio financeiro, porém, ao valor total de 16 bilhões de reais.

Também foi aprovada a Lei Complementar no 173 de 27 de maio de 2020, que instituiu o denominado Programa Federativo de Enfrentamento ao Coronavírus SARS-CoV-2 (Covid-19). Além de relevantes alterações nos artigos 61 e 65 da LRF, o programa previu a concessão de "auxílio financeiro"1 a Estados, DF e Municípios no total de 60 bilhões de reais, sob determinadas condições, e suspendeu temporariamente os pagamentos de dívidas contratadas entre a União e os demais entes federativos. Especificamente para os Municípios, também suspendeu os pagamentos dos refinanciamentos de dívidas com a Previdência Social.

Por outro lado, os pleitos dos contribuintes começaram a chegar ao Poder Judiciário. Inúmeras demandas foram ajuizadas com a pretensão de suspender a exigibilidade dos tributos e excluir os consectários legais do inadimplemento, fundamentadas na ocorrência de "fato do príncipe" impeditivo do regular adimplemento tributário e na aplicação analógica da Portaria MF n 12, de 20 de janeiro 2012 (que autoriza a prorrogação do vencimento de tributos federais quando declarado estado de calamidade pública).

No que tange aos tributos municipais, um dos casos que chegou ao Supremo Tribunal Federal foi a Suspensão de Segurança 5374, ajuizada pelo Município de São Paulo contra decisão do Tribunal de Justiça daquele Estado que determinara, em tutela de urgência, a suspensão da exigibilidade dos impostos sobre serviços (ISSQN) e sobre a propriedade imobiliária urbana (IPTU), bem como das obrigações acessórias correlatas, pelo prazo de 60 dias e sem a incidência de quaisquer penalidades, em favor de determinado grupo econômico.

A suspensão dos efeitos da decisão, proferida pelo tribunal paulista, foi deferida pelo Ministro Dias Toffol em decisão monocrática, na qual destacou que o potencial efeito multiplicador de decisões individuais com tal conteúdo representava sério risco de dano para a economia e a ordem administrativa locais. Ressaltou, ainda, que:

Não se ignora que a situação de pandemia, ora vivenciada, impôs drásticas alterações na rotina de todos, atingindo a normalidade do funcionamento de muitas empresas e do próprio poder público, em diversas áreas de atuação. Mas, exatamente em função da gravidade da situação, exige-se a tomada de medidas co- 


\begin{abstract}
ordenadas e voltadas ao bem comum, não se podendo privilegiar determinado segmento da atividade econômica em detrimento de outro, ou mesmo do próprio poder público, a quem incumbe, precipuamente, combater os nefastos efeitos decorrentes dessa pandemia. Assim, não cabe ao Poder Judiciário decidir quem deve ou não pagar impostos, ou mesmo quais políticas públicas devem ser adotadas, substituindo-se aos gestores responsáveis pela condução dos destinos do Estado, neste momento. [...] Ademais, a subversão, como aqui se deu, da ordem administrativa vigente no município de São Paulo, em matéria tributária, não pode ser feita de forma isolada, sem análise de suas consequências para o orçamento estatal, que está sendo chamado a fazer frente a despesas imprevistas e que certamente têm demandado esforço criativo, para a manutenção das despesas correntes básicas do município. (SS 5374, 2020, p. 8).
\end{abstract}

A decisão representa a postura que foi adotada pelo Poder Judiciário, de maneira geral: autocontenção e deferência ao Poder Executivo, que teve reafirmada sua competência para a definição de políticas públicas econômicas.

Nesse cenário, proclamada a necessidade de soluções sistêmicas para a crise, surge para a Administração Pública o poder-dever de exercer a tributação com finalidade não apenas arrecadatória, mas também e de forma muito peculiar, extrafiscal, com o objetivo de manutenção das fontes de emprego e de renda. Sem as quais, em um futuro próximo, a arrecadação tributária e os serviços públicos por ela financiados restariam gravemente ameaçados.

Daí nascem as possibilidades de aplicação do Direito Tributário sob um viés especial, em que determinados institutos e regras ganham destaque por sua acentuada utilidade em tempos de crise, formando uma espécie de regime jurídico de emergência, tanto para o ente público quanto para o contribuinte. Cabe analisar, então, quais dos institutos tributários tradicionalmente estudados compõem esse regime especial.

\title{
2.1 MORATÓRIA
}

Apesar de não constar expressamente do CTN, a moratória é instituto de aplicação excepcional, a ser concedida em virtude de situações naturais, econômicas ou sociais extraordinárias que dificultem o normal adimplemento das obrigações tributárias (ALEXANDRE, 2020).

Parece inquestionável, então, que a crise sanitária e econômica gerada pelo novo coronavírus com o isolamento social (e, em algumas partes do mundo, "lockdown") que the acompanhou, configuram uma evidente hipótese de cabimento da moratória. Assim, a primeira consideração a ser feita quanto ao instituto é de caráter distintivo, traçando as características que a distinguem a moratória da prorrogação do prazo de pagamento de tributos.

A moratória é causa de suspensão da exigibilidade do tributo prevista no artigo 151, inciso I, do Código Tributário Nacional, que, em regra, impede a exigência de crédito já constituído. Diz-se em regra porque o artigo 154 cuidou de prever a possibilidade de a moratória, caso exista previsão legal nesse sentido, também suspender a exigibilidade de crédito cujo lançamento sequer tenha se iniciado. Sobre essa hipótese incomum, Carvalho (2004, p. 439) explica que: 


\begin{abstract}
dos no modo da lei (pelo lança mento), possam enquadrar-se, postulando seus benefícios. Mas de que maneira? Apresentando à autoridade administrativa competente uma declaração em que tudo aquilo que o lançamento contém esteja claramente discriminado. [...] Nessas condições, antecipa-se o devedor, oferecendo os dados integrais que seriam expressos no ato de lançamento, e predica sua inclusão para desfrutar dos prazos mais dilargados que a lei da moratória prevê.
\end{abstract}

Por sua vez, a prorrogação é apenas a alteração da norma que prevê o prazo final de pagamento do tributo, postergando a data após a qual a prestação pecuniária se considerará vencida. Se não adimplida, passará a ser acrescida dos encargos da mora previstos em lei, como juros e multa. A prorrogação do prazo, portanto, só beneficia o contribuinte no que se refere àqueles tributos ainda não vencidos ao tempo da alteração, os quais passam a ter nova data de vencimento, conferindo um tempo maior para recomposição do fluxo de caixa.

Já a moratória, uma vez concedida, pode alcançar tributos vencidos no passado e interromper o crescimento da dívida já existente na medida em que faz cessar os efeitos da mora por período predeterminado, durante o qual fica suspensa a exigibilidade do tributo. Nesse sentido é que a moratória traz à tona o princípio da indisponibilidade dos bens públicos, razão essencial também para que o assunto seja posto ao regime de exclusiva legalidade (CARVALHO, 2004).

A distinção material, portanto, tem uma repercussão formal relevantíssima: a moratória se submete à reserva de lei em sentido estrito, enquanto o diferimento do tributo não. Por força do art. 146, inciso III da Constituição da República, só a Lei Complementar pode dispor, em caráter geral, sobre crédito tributário. Nessa linha, os artigos 97, inciso VI e 153 do CTN, que foi recepcionado com status de Lei Complementar, exigem edição de lei em sentido estrito para a concessão de moratória, seja ela geral ou individual.

Por outro lado, a previsão e alteração do prazo de vencimento do tributo, tanto para prorrogá-lo quanto para adiantá-lo, podem ser feitas por via infralegal, sendo matéria afeta à "legislação tributária" entendida de maneira ampla, conforme prevê o artigo 96 do CTN. Aliás, há muito é consolidado no Supremo Tribunal Federal o entendimento de que o prazo para recolhimento de tributo não é matéria submetida ao princípio da legalidade tributária (RE 140.669/PE, rel. Min. IImar Galvão, j. 02/12/1998), nem ao da anterioridade tributária. O que inclusive resultou na edição da Súmula Vinculante $n^{\circ} 50$ : "Norma legal que altera o prazo de recolhimento de obrigação tributária não se sujeita ao princípio da anterioridade."

De fato, uma das primeiras medidas de caráter tributário editadas no contexto da pandemia foi a Resolução do Comitê Gestor do Simples Nacional $n^{\circ} 152$ de 18 de março de 2020, prevendo a prorrogação do prazo para pagamento dos tributos federais no âmbito do Simples. Essa celeridade dificilmente seria obtida por meio do processo legislativo ordinário.

Dessa forma, a opção política pelo diferimento do tributo em vez da moratória traz o conveniente de não se depender do Poder Legislativo local nem do tempo que geralmente a tramitação do processo legislativo requer, possibilitando ação imediata do Poder Executivo e uma produção mais rápida dos efeitos econômicos pretendidos. Por outro lado, o diferimento do prazo de pagamento beneficia a todos os contribuintes, indistintamente, ainda que se saiba que nem todos absorvem a crise econômica da mesma forma. A depender do perfil do 
contribuinte (v.g. se pessoa física ou jurídica, se sociedade empresária de pequeno, médio ou grande porte, etc) e do tipo de atividade econômica desenvolvida, o grau de comprometimento da capacidade contributiva pode variar bastante.

Alguns dados confirmam que certos setores da economia sofreram muito mais do que outros com a crise sanitária e o isolamento social. Em pesquisa divulgada pela Deloitte (2020), consta que no período de março a maio de 2020 foi registrada uma queda de $62 \%$ no faturamento do setor de serviços e, entre fevereiro e março de 2020 , houve queda de $38 \%$ na produção de artigos de vestuário e acessórios. Por outro lado, a demanda por serviços de internet de banda larga aumentou $70 \%$ desde o começo da quarentena no país, assim como a produção de produtos de higiene e limpeza registrou um aumento de $22 \%$ em abril de 2020.

À vista dessas diferenças, deve-se lembrar que, por autorização expressa no parágrafo único do artigo 152 do CTN, a lei concessiva de moratória pode circunscrever a sua aplicabilidade não só à determinada região do território como também a determinada classe ou categoria de sujeitos passivos. Sendo o caso de moratória concedida em caráter individual, o contribuinte deverá comprovar à autoridade administrativa o preenchimento dos requisitos e condições previstos na lei concessiva do benefício. Nessa hipótese, o legislador poderá, a partir de uma prévia análise de dados, direcionar a moratória aos setores da economia comprovadamente mais impactados com a crise, ou mesmo condicionar a sua concessão a demonstrativos concretos de redução da capacidade contributiva do contribuinte. Por exemplo, seria possível condicionar o gozo de moratória de ISSQN à comprovação contábil de significativa queda no faturamento mensal do contribuinte em comparação com o mesmo período de anos anteriores.

Ricardo Lobo Torres (2011) trata a capacidade contributiva como subprincípio da justiça fiscal, segundo o qual cada um deve contribuir na proporção de suas rendas e haveres, e que no Brasil é previsto expressamente no art. $145 \S 1^{\circ}$ da Constituição. Nessa linha, parece correto afirmar que o diferimento do tributo não tem a mesma aptidão que a moratória para realizar a justiça fiscal e, em última análise, a isonomia, já que o diferimento acaba por tratar da mesma maneira contribuintes que se encontram em situações econômicas distintas.

Ainda, é interessante observar as diferenças entre um e outro à luz do controle de legalidade orçamentária. Nos termos do art. $14 \S 1^{\circ}$ da $L R F$, a renúncia de receita compreende "anistia, remissão, subsídio, crédito presumido, concessão de isenção em caráter não geral”, alteração de alíquota ou de base de cálculo que implique redução discriminada de tributos ou contribuições, "e outros benefícios que correspondam a tratamento diferenciado." Nota-se que, além dos institutos nomeados expressamente pelo legislador, a definição legal só impõe as exigências dos incisos I e II do artigo 14 aos tratamentos tributários que diferenciem contribuintes, excluindo, nesse sentido, a isenção concedida em caráter geral.

Assim, em tese a moratória individual poderia suscitar controvérsia quanto à necessidade de cumprimento ou não do art. 14 da LRF, embora vejamos duas incompatibilidades em considerá-la como renúncia. A primeira dificuldade, de caráter teórico, é que a moratória apenas suspende a exigibilidade, fazendo cessar os juros de mora e evitando a incidência 
(ou agravamento) de multa que seriam devidos a partir da sua concessão. Ou seja, ao contrário da remissão, a moratória não se dá sobre crédito já existente, mas sobre uma mera expectativa eventual de receita. Seria uma espécie de abdicação de receita futura e incerta, na medida em que não se pode afirmar com certeza que o contribuinte continuaria em mora ou por quanto tempo. A segunda dificuldade, de caráter prático, decorrente da primeira, é a difícil metodologia do cálculo que seria necessário para estimar o quantitativo de receita objeto de renúncia, para fins de cumprimento da LRF, sobretudo os arts. 12 e 14.

Contudo, vale destacar que além da dispensa dos requisitos legais de renúncia fiscal que foi trazida pela Emenda Constitucional 106 (art. $3^{\circ}$ ), em caráter específico e restrito ao estado de calamidade declarado em virtude da Covid-19, a LC 173/2020 trouxe importantes alterações legislativas sobre a matéria. Foi introduzido o parágrafo $1^{\circ}$ ao art. 65 da LRF, afastando as condições e vedações previstas nos arts. 14, 16 e 17 da LC 101/00 em qualquer caso de declaração de calamidade pública pelo Congresso Nacional, "desde que o incentivo ou benefício e a criação ou o aumento da despesa sejam destinados ao combate à calamidade pública.", expressão que, por responsabilidade e prudência fiscal, pensamos que deva ser interpretada restritivamente.

Por fim, pode-se dizer que tanto a moratória quanto o diferimento beneficiam o contribuinte, em maior ou menor grau, haja vista que o prazo adicional para pagamento do tributo propicia um "fôlego" para que o sujeito passivo possa restabelecer seu regular fluxo de caixa.

Nesse sentido, ao gestor prudente é imprescindível analisar a incidência da vedação existente em ano eleitoral, prevista no artigo $73 \S 10$ da Lei $n^{\circ}$ 9.504/1997, que dispõe que "No ano em que se realizar eleição, fica proibida a distribuição gratuita de bens, valores ou benefícios por parte da Administração Pública, exceto nos casos de calamidade pública, de estado de emergência" e outras exceções elencadas pela lei.

A configuração do que seja "distribuição gratuita" de benefícios, muitas vezes, depende da análise do caso concreto. Nesse sentido o Tribunal Superior Eleitoral, ao responder a consulta 36.815/DF em 03/03/2015, definiu que "A validade ou não de lançamento de Programa de Recuperação Fiscal (Refis) em face do disposto no art. 73, § 10, da Lei $n^{\circ}$ 9.504/1997 deve ser apreciada com base no quadro fático-jurídico extraído do caso concreto".

A vedação da lei eleitoral tem por finalidade preservar a igualdade da competição eleitoral, evitando a manipulação da máquina pública de modo a conquistar simpatizantes para determinada candidatura (TSE. Consulta 1531-69/DF. Relator: ministro Marco Aurélio. 20/9/2011). Por isso, a exceção expressa para o caso de calamidade pública parece perfeitamente justificável, sendo nesse sentido mesmo a jurisprudência do TSE (Recurso Especial Eleitoral n 79973, Acórdão, relator ministro Herman Benjamin, Publicação: DJE 25/05/2016, p. 51).

Embora expressa a previsão legal, não se dispensa, é claro, o dever de fundamentação dos atos concessivos de benefícios tributários a serem editados. 
Da exposição, pode-se concluir que a moratória é instituto mais vocacionado à justiça fiscal do que o diferimento dos tributos, mas, por ser acompanhada de mais exigências formais e requisitos procedimentais, pode acabar se tornando, na prática, uma opção não tão atraente ao gestor que pretenda dar uma resposta mais rápida à crise econômica.

\subsection{PARCELAMENTO}

O parcelamento é uma das medidas fiscais mais comuns entre os programas de recuperação fiscal (REFIS). Trata-se de "medida de política fiscal com a qual o Estado procura recuperar créditos e criar condições práticas para que os contribuintes que se colocaram numa situação de inadimplência tenham a possibilidade de voltar para a regularidade, usufruindo os benefícios daí decorrentes." (ALEXANDRE, 2017, p. 486).

Em poucas palavras, consiste na autorização legal para divisão do crédito tributário (principal, juros e multa) em diversas parcelas, sendo apenas uma forma especial de realizar o pagamento (parcelamento puro). É comum, porém, que, em conjunto, sejam concedidos outros benefícios fiscais, como a concessão de descontos na multa e nos juros, para incentivar a adesão do contribuinte (parcelamento incentivado).

Como o Código Tributário Nacional prevê no art. 155 que a forma e as condições para formalização do parcelamento devem ser previstas em lei específica, cada ente federativo tem autonomia para editar suas próprias leis autorizativas, com a respectiva regulamentação.

É previsto no art. 151, VI do Código Tributário Nacional como uma causa de suspensão da exigibilidade do crédito, pois enquanto o contribuinte estiver cumprindo o acordado no termo de adesão ao programa de parcelamento, o crédito tributário não é exigível por outras vias como a ação judicial de execução fiscal. Apesar de ser causa de suspensão da exigibilidade, é também causa interruptiva da prescrição, pois, como deriva de acordo celebrado com o contribuinte, entende-se que há o reconhecimento da dívida por parte deste (art. 174, parágrafo único, IV do CTN).

O parcelamento é uma medida muito eficaz para o ingresso imediato de recursos, pois a concessão de condições mais favoráveis para o pagamento gera adesão em massa de devedores que querem, ou precisam, regularizar sua situação perante o fisco. Então, pode ser uma boa alternativa para os Municípios que tiverem queda brusca na arrecadação e que precisam de recursos de forma imediata para fazer frente às novas despesas geradas pela pandemia.

Por outro lado, o parcelamento pode ser uma medida temerária se não houver um planejamento a longo prazo. Isso porque a periodicidade dos programas de parcelamento pode estimular uma cultura do inadimplemento. Há o risco de que os contribuintes, ao tomarem suas decisões financeiras, façam a opção pela inadimplência dos tributos, confiando em futura adesão a um programa de parcelamento para o retorno à situação de regularidade fiscal.

A frequência constante de programas de parcelamento gera um processo cíclico de desestímulo ao adimplemento espontâneo, queda na arrecadação ordinária, que, por sua 
vez, gera a necessidade de mais programas de parcelamento para estímulo no ingresso de recursos.

No âmbito federal, entre 2000 e 2010 foram lançados quatro programas de regularização fiscal, de três em três anos (2000, 2003, 2006 e 2009). Pelos dados fornecidos pela Receita Federal, observa-se que no primeiro ano do programa lançado em 2000, a arrecadação média mensal era de R\$ 176 milhões. Já no primeiro ano do programa lançado em 2009, a arrecadação média mensal aumentou para R\$ 948 milhões (PAES, 2012).

Diversos fatores podem ter contribuído para esse aumento na arrecadação. Em 2009 o mundo ainda sentia os efeitos da crise econômica de 2008, o que provavelmente influenciou no índice de adimplemento regular de obrigações tributárias e na maior adesão ao programa de regularização fiscal. Porém, esse aumento significativo pode ser um indicativo de que em situação de crise, em que é preciso escolher qual obrigação adimplir, as obrigações tributárias ficam em segundo plano. Indo além, pode ser que essa escolha do contribuinte tenha sido influenciada pela regularidade com que o governo vinha autorizando os parcelamentos tributários na época, pois o contribuinte sabia que se deixasse de pagar, teria oportunidade futura de se regularizar sem muitas penalidades.

Portanto, não seria de se espantar que, na crise atual em virtude da pandemia, Municípios que já mantenham a prática de lançar programas periódicos de parcelamento sintam um impacto maior na arrecadação do que aqueles que não têm essa prática. Trata-se de hipótese que só poderá ser confirmada, ou não, por estudos futuros após o impacto inicial da crise.

O que se tem observado na prática, até o momento, é que Municípios que já tinham programas de parcelamento vigentes editaram atos normativos impedindo a rescisão ou rompimento do acordo pelo inadimplemento das parcelas. Trata-se de medida fiscal de solidariedade, considerando que inadimplência não é decorrente da desídia do contribuinte, mas sim consequência de um contexto global de emergência em saúde pública.

Os efeitos dessa medida serão sentidos em curto prazo. Além do impacto da queda do adimplemento voluntário, em virtude da crise, esses Municípios vão sentir o impacto da queda do adimplemento dos acordos de parcelamento. Sem a rescisão ou rompimento dos acordos no âmbito administrativo, as cobranças judiciais ficam paralisadas pela suspensão da exigibilidade do crédito, inviabilizando a arrecadação de toda essa parcela da dívida ativa que foi objeto do programa. O que era um programa para incentivar a arrecadação se tornou um repositório, temporariamente intocável, de dívida ativa.

Já os Municípios que não tem como prática a política de parcelamento periódica, acabam tendo essa medida como uma opção para enfrentar esse momento de crise econômica. O programa de parcelamento nesse contexto representa uma alternativa para os Municípios que precisam manter imediatamente o nível de arrecadação, para fazer frente às novas despesas; e representa um incentivo não só para os contribuintes que são inadimplentes e precisam se regularizar, mas também para os contribuintes que têm o hábito de pagar voluntariamente, mas se encontram impossibilitados. 
Inclusive, uma ferramenta interessante para o momento é o parcelamento especial para empresas em recuperação judicial. O Código Tributário Nacional, nos parágrafos $3^{\circ} \mathrm{e}$ $4^{\circ}$ do art. 155-A, incluídos pela Lei Complementar $n^{\circ} 118 / 2005$, disciplina a preferência por uma política específica de parcelamento para os créditos tributários do devedor em recuperação judicial, separada do parcelamento geral.

Economistas estimam um aumento no número de pedidos de recuperação judicial de empresas. Segundo o jornal O Globo, o recorde, até então, de pedidos se deu no ano de 2016, em que houve aproximadamente 1800 pedidos registrados. A estimativa para o ano de 2020 é entre 2 a 5 mil pedidos (BRANCO, 2020).

Portanto, como a concessão de recuperação judicial depende da apresentação da prova de quitação dos tributos (art. 191-A do Código Tributário Nacional), é interessante que os Municípios que tenham médias e grandes empresas, capazes de se enquadrar no perfil da Lei $n^{\circ} 11.101 / 2005$, criem um parcelamento especialmente direcionado a elas.

A Lei $\mathrm{n}^{\circ} 11.101 / 2005$ não é direcionada para médias e grandes empresas, mas na prática, são elas que mais se utilizam desse instrumento judicial. Um estudo realizado pelo Observatório da Insolvência, iniciativa do Núcleo de Estudos de Processos de Insolvência (NEPI) da PUC de São Paulo e da Associação Brasileira de Jurimetria (ABJ) indicou uma "desproporção entre a distribuição geral das pessoas jurídicas registradas perante as juntas comerciais (em situação de crise ou não) e a distribuição das pessoas jurídicas que requerem a recuperação judicial" (WAISBERG et al., 2018, p. 5).

De um total de 906 processos de recuperação judicial analisados no Estado de São Paulo entre janeiro de 2010 e julho de 2017, 92 (10,1\% do total) foram requeridos por microempresas (ME), 94 (10,3\%) por empresas de pequeno porte (EPP), 182 (20\%) por grupos societários e 538 (59,3\%) por médias e grandes empresas (WAISBERG et al., 2018).

Os motivos para esse fenômeno são diversos, o alto custo de um processo de recuperação judicial, a burocracia, o receio da desconfiança que pode ser gerada por assumir uma dificuldade financeira. Mas o fato é que enquanto as micro e pequenas empresas são a grande maioria das empresas registradas nas juntas comerciais, elas são a grande minoria das empresas que tem acesso à recuperação judicial.

Isso significa que existe um grande contingente de micro e pequenas empresas que não estaria incluída nessa medida, pois não chegam a submeter ao Poder Judiciário um pedido de recuperação judicial. Parte dessas empresas estão incluídas no Simples Nacional, regime instituído pela Lei Complementar $n^{\circ} 123 / 2006$, que unifica os tributos devidos a todos os entes na Receita Federal. Para elas, a medida publicada pela Receita Federal foi a Resolução do Comitê Gestor do Simples Nacional n 154, de 3 de abril de 2020, que trata da prorrogação do vencimento de tributos apurados por dentro no âmbito do Simples Nacional, incluindo os tributos municipais.

Porém, como se trata de regime facultativo, parte delas podem ser abrangidas pelos Municípios em programas de parcelamento com condições especiais. Trata-se de medida que deve ser estudada com cuidado, com base na realidade de cada Município, mas que 
pode trazer muitos benefícios, já que são essas empresas as mais ligadas ao comércio e à movimentação do dia a dia, que foram diretamente afetadas pelas medidas de quarentena.

De tudo o que foi exposto é possível concluir que o parcelamento tributário é uma medida eficaz para enfrentar esse momento inédito de difícil conciliação entre o que é preciso e o que é possível fazer diante das circunstâncias que foram impostas pela realidade. Especialmente para os Municípios que não utilizavam esse instrumento de forma frequente, o programa de regularização fiscal pode ser um importante incentivo para aquele contribuinte que está passando por dificuldades, mas não quer exercer suas atividades de forma irregular.

\subsection{TRANSAÇÃO}

A transação é, por definição legal, a forma de extinção do crédito tributário que se realiza mediante concessões recíprocas, nas condições que a lei estabeleça, importando em terminação de litígio (arts. 156, III e 171 do CTN). Porém, "é curioso verificar que a extinção da obrigação, quando ocorre a figura transacional, não se dá, propriamente, por força das concessões recíprocas, e sim do pagamento." (CARVALHO, 2004, p. 61). Essa singela observação resolveria muitas complicações práticas que decorrem da previsão, em algumas leis municipais e estaduais, de que celebrada a transação, é obrigatória a desistência das execuções fiscais que versem sobre o crédito transacionado. Evidentemente, só deve haver a desistência do processo executivo quando extinto o crédito pelo pagamento, não bastando a celebração da transação, ainda que esta seja formalmente prevista no CTN como causa extintiva.

Na prática, o mais comum é que a transação apareça combinada com outros institutos. Os programas de parcelamento e refinanciamento de dívidas tributárias, por exemplo, os chamados "refis", são, na maioria das vezes, "parcelamentos incentivados", como já referido.

De um lado, geralmente a lei prevê que, para ter direito ao parcelamento, o contribuinte deve confessar expressamente o débito (fato que interromperá a prescrição, em seu desfavor), desistir de impugnações e recursos bem como renunciar aos direitos discutir judicialmente o débito, seja em ação já proposta ou futura. De outra parte, a Fazenda renuncia a parte dos valores devidos a título de multa e juros de mora (anistia e remissão) e permite o pagamento parcelado do saldo recalculado da dívida, ou, ainda, pagamento à vista, mediante um desconto geralmente maior.

Os acordos assim previstos, corriqueiramente, nas leis dos "Refis", têm conteúdo de transação. São, na verdade, uma mescla de vários institutos: anistia e remissão (das multas, por exemplo), parcelamento e pagamento, o que se caracteriza pela expressão "concessões mútuas" a serem firmadas entre os sujeitos ativo e passivo da obrigação tributária cujo objetivo é a terminação do litígio - erroneamente mencionada pelo CTN como "determinação" - e a extinção do crédito (SCAFF, 2014).

Entendida assim de maneira ampla, pode-se afirmar que a transação já é há muito tempo praticada, não só na União, mas também em Estados e Municípios, embora tenha ga- 
nhado mais destaque recentemente, por conta da crise do novo coronavírus. Foi no contexto da pandemia que a Medida Provisória $n^{\circ} 899$ de 16 de outubro de 2019 foi convertida na Lei 13.988 de 14 de abril de 2020, que prevê hipóteses, condições e procedimentos para a realização da transação tributária em âmbito federal, instituindo duas modalidades: a transação por proposta individual (iniciativa do contribuinte) e a por adesão (edital público ao qual os interessados que preencham os requisitos legais podem aderir). Embora aplicável apenas para as transações realizadas pela União, certamente a lei poderá servir de parâmetro para outros entes que ainda não tenham disciplinado a matéria.

Observa-se que a Lei 13.988 adotou o entendimento perfilhado por grande parte da doutrina de que o litígio resolvido pela transação tributária pode estar apenas instaurado na instância administrativa (CARVALHO, 2004, p. 462), admitindo a transação quanto a créditos ainda não judicializados (art. $1^{\circ}, \S 4^{\circ}$, inc. I). A propósito, vale lembrar que, ao contrário do que ocorre no Direito Civil, a transação tributária é somente terminativa de litígio, não se admitindo a preventiva.

Além disso, a lei também positivou o entendimento de que a transação não é uma forma de novação dos créditos transacionados; descumprido o acordo e rescindido, restaura-se o crédito sem nenhum dos benefícios anteriormente concedidos, somente sendo extinto o crédito mediante cumprimento total da transação (art. $3^{a}, \S 3^{\circ}$ e art. $4^{\circ}, \S^{\circ}$ ).

Tendo como um dos objetivos reduzir o número de litígios e os custos que lhes são inerentes, a Portaria do Ministério da Economia n 247/2020 do regulamentou duas hipóteses de cabimento da transação previstas na lei federal: a de créditos sob "relevante e disseminada controvérsia jurídica" (definida no art. 30) e os "de pequeno valor" (art. 32). O encerramento de litígios sobre créditos que envolvam tema de controvérsia qualificada nos termos da lei é, ainda, sob o ponto de vista da segurança jurídica, particularmente interessante, pois, ressalvada a superveniência de precedente previsto nos incisos I a IV do art. 927 do CPC (Lei n 13.105, de 2015), fica o contribuinte sob a "eficácia prospectiva da transação", que é a sujeição ao entendimento dado pela Administração tributária à questão em litígio também em relação aos fatos geradores futuros ou ainda não consumados (art. $19, \S 1^{\circ}$, II da lei).

A Portaria $n^{\circ} 247 / 2020$ também trouxe a autorização, no seu artigo $7^{\circ}$, de que o edital de transação preveja descontos sobre o montante principal do tributo, o que reacende um debate interessante nos estudos sobre transação. A névoa geralmente existente sobre a questão de redução do valor do próprio tributo e não apenas de juros e multa, é a do famigerado princípio da indisponibilidade do interesse público. Todavia, Cleide Regina Furlani Pompermaier (2020) muito bem adverte que já é prática antiga e nada contestada a previsão, em leis municipais, de desconto percentual fixo no valor do Imposto de Propriedade Territorial Urbano quando pago à vista e até certa data, um dos muitos exemplos que demonstram que o temor quanto ao tema não resiste a uma análise mais acurada.

Porém, por se tratar de redução do valor do próprio tributo, consideramos que só pode ser autorizada por lei em sentido estrito, por força do artigo 97 do CTN. Do mesmo modo, as condições e requisitos para a transação devem ser sempre previstos em lei e da forma 
mais objetiva possível, não podendo o ato regulamentador do procedimento dispor mais do que a lei autorizadora.

Por outro lado, também foi editada a Portaria PGFN n 14.402, de 16 de junho de 2020, que disciplina a denominada "transação excepcional", diretamente voltada aos efeitos da COVID-19. Com o propósito declarado de ajustar a expectativa de receita tributária à capacidade de pagamento dos devedores, viabilizando a superação da crise econômico-financeira e a preservação da fonte produtora, do emprego e da renda dos trabalhadores (art. $2^{\circ}$ ).

A Portaria vai ao encontro do ideal de tratamento personalizado aos contribuintes em dificuldade financeira, com maior realização da Justiça Fiscal, pois condiciona a adesão à transação à verificação do real impacto da crise na capacidade de geração de resultados dos contribuintes pessoa jurídica. Além do uso de dados de outras fontes pela Fazenda Nacional, permite ao contribuinte a demonstração contábil da redução da receita bruta mensal apurada em 2020 comparada com o mesmo período de 2019.

Dessa forma, a Lei 13.988/2020 e os atos editados para sua regulamentação (nem todos citados aqui) formam um cenário normativo em que é possível enxergar duas perspectivas de aplicação da transação: como forma de resolução de litígio e como forma emergencial de arrecadação. Esta última, contudo, sem descuidar dos objetivos extrafiscais de preservação das engrenagens econômicos em um cenário de crise.

Como referencial para os demais entes federativos, sem dúvidas está a racionalização da transação conforme a categorização dos créditos, que leve em conta o grau de recuperabilidade da dívida, o perfil do devedor e o estado do processo, classificações a serem feitas por critérios objetivos e predeterminados, que podem ser aplicáveis também a outros benefícios tributários, como a remissão e a anistia. Nesse sentido, um exemplo interessante é o da Lei Municipal $n^{\circ} 8.532 / 2017$ de Blumenau/SC, que, ao prever requisitos para a transação, estabelece uma tabela de pontuação que vai de zero a cinco, na qual se considera, a partir de cada caso em particular, o histórico fiscal do devedor, sua situação econômica, a economicidade da medida, o tempo de duração do processo em Juízo, chances de êxito na causa e, finalmente, a existência de precedentes jurisprudenciais contra a tese do credor já pacificados por súmula dos tribunais superiores, repercussão geral ou recursos repetitivos (POMPERMAIER, 2020).

Por fim, quanto ao aspecto da responsabilidade fiscal, vale mencionar a Consulta 17/00707865, apresentada pelo Município de Blumenau/SC, que atua na vanguarda do tema, perante o Tribunal de Contas do Estado de Santa Catarina, na qual se encontram valiosas respostas sobre o instituto da transação. Para os fins deste artigo, destacam-se as respostas ao segundo e terceiro questionamentos lá formulados: i) possibilidade de renúncia parcial do crédito tributário mediante desconto no valor principal do tributo, registrada a impossibilidade de renúncia total, pois esta eliminaria a reciprocidade de concessões que caracteriza a transação, equiparando o instituto à mera remissão; ii) a transação configura renúncia de receita e a estimativa desta deve ser considerada nas Lei de Diretrizes Orçamentárias e Lei Orçamentária Anual do respectivo exercício financeiro em que será realizada, com a necessária observância das condições do art. 14 da LRF. 
Portanto, sendo o desconto de crédito tributário já constituído uma das concessões feitas pelo Fisco, haverá renúncia de receita, mais um motivo para se reafirmar que a lei autorizadora da transação deve estabelecer requisitos e critérios bem definidos e objetivos, de modo a evitar a discricionariedade da autoridade fazendária na decisão do que e do quanto conceder.

Como conclusão, tem-se que, além de instrumento de redução da litigiosidade entre contribuintes e Administração, a transação é uma possibilidade para manutenção da eficiência da arrecadação sem aumento da carga tributária.

\subsection{DAÇÃO EM PAGAMENTO}

A dação em pagamento não é um instituto propriamente tributário, mas sim emprestado do Direito Civil. Trata-se de uma forma de extinção das obrigações em geral, por meio do qual o credor aceita "prestação diversa da que lhe é devida" (SCHREIBER, 2018).

No Direito Tributário, conforme dispõe o art. $3^{\circ}$ do CTN, a prestação é sempre pecuniária, em moeda ou cujo valor nela se possa exprimir. Dessa forma, a dação em pagamento ocorre sempre que a Fazenda aceita o pagamento de tributos por outro meio que não seja dinheiro.

Porém, em razão do princípio da legalidade, é necessária autorização legal para que o Estado consinta no pagamento de tributos por outro meio que não o pagamento em dinheiro. $\mathrm{O}$ art. 156, XI do CTN prevê como forma de extinção do crédito tributário "a dação em pagamento em bens imóveis, na forma e condições estabelecidas em lei" (incluído no CTN em 2001). Portanto, o CTN permite a dação em pagamento por meio de bens imóveis, se houver legislação do ente tributante com previsão nesse sentido.

Questão que sempre surge quando se fala sobre dação em pagamento é se seria possível o pagamento de tributos por meio de outras prestações além dos bens imóveis, como bens móveis ou prestação de serviços. Em um contexto de crise sanitária como a que se está vivendo, poderia ser interessante pensar em um instrumento que permitisse, por exemplo, que setores ligados ao combate à pandemia pudessem quitar créditos tributários inscritos em dívida ativa, com a prestação de serviços essenciais a esse combate.

Seria o caso, por exemplo, de um hospital privado, que pudesse fornecer leitos de UTI, ou de uma indústria têxtil que pudesse fornecer equipamentos de proteção individual para os profissionais de saúde, ou laboratórios que pudessem auxiliar na testagem. Enfim, poderiam ser mobilizados todos os setores que tem algo a contribuir para o combate à pandemia, para quitação de créditos tributários, inscritos em dívida ativa, por meio da prestação desses serviços.

Há precedentes no Supremo Tribunal Federal que podem servir de parâmetro para análise da constitucionalidade de eventual medida nesse sentido. Tratam-se de duas ações diretas de inconstitucionalidade em que o STF discutiu a possibilidade de os entes federativos preverem outras formas de extinção do crédito tributário, diversas das previstas no CTN.

A primeira delas é a ADI 1917/DF. No julgamento da medida cautelar (ocorrido em 
1998, com publicação em 2003) dessa ação, o STF suspendeu a eficácia de norma distrital que previa a dação em pagamento como forma de extinção do crédito tributário, em razão de as causas de extinção estarem definidas em lei complementar nacional. Portanto, a primeira posição adotada pelo STF foi no sentido de que somente o CTN poderia prever as formas de extinção do crédito tributário, aderindo à concepção de um rol taxativo.

A segunda delas é a ADI 2405/RS. Também em sede cautelar (cujo julgamento ocorreu em 2002, com publicação em 2006), o STF alterou o posicionamento anteriormente adotado na ADI 1917/DF, passando a entender pela possibilidade de o Estado-membro estabelecer regras específicas de quitação de seus créditos tributários.

No inteiro teor do acórdão fica claramente consignado que as únicas formas de extinção do crédito tributário que possuem reserva de lei complementar são a prescrição e a decadência (art. 146, III, "b" da CRFB).

Dessa forma, os Estados estariam autorizados a prever outras formas de extinção de seus créditos. No que se refere à dação em pagamento, o acórdão ressalta que muitas leis estaduais já a previam como forma de extinção do crédito, antes mesmo da inclusão do inciso XI no art. 156 do CTN (que ocorreu em 2001); e que a limitação da dação em pagamento em bens imóveis não exclui outras formas de prestação previstas nas leis estaduais.

Como observou o então Ministro Moreira Alves, "se o Estado pode o mais, até mesmo anistiar, e portanto, abrir mão de seu crédito, ele pode o menos, admitir uma forma de pagamento, que, no caso, sequer compele a Fazenda a recebe-lo, porque exige a aceitação por parte do orçamento" (ADI 2405/RS MC, 2002, p. 114).

Quando do julgamento do mérito da ADI 1917/DF, em 2007, o STF não se prendeu à análise da questão sob a ótica da necessidade ou não de lei complementar, tendo em vista que essa questão já havia sido definida no julgamento da cautelar da ADI 2405/RS. Dessa forma, o julgamento pela inconstitucionalidade da norma distrital teve como fundamento outro argumento, externo à questão tributária: a obrigatoriedade da licitação para a contratação de bens e serviços pela Administração Pública (art. 37, XXI da CRFB).

Decidiu-se pela inconstitucionalidade da dação em pagamento em bens móveis e prestação de serviços por violação do princípio da licitação e do princípio da isonomia. Se fosse permitida essa modalidade de extinção do crédito tributário, seriam privilegiados os fornecedores de bens e serviços com débitos em aberto, que evitariam a licitação e a concorrência com fornecedores que se encontram sem débitos, gerando uma distorção no mercado.

Foi pontuado no acórdão que, do modo como a norma distrital foi posta, houve permissão para um regime de aquisição de bens paralelo ao regime da licitação. Uma substituição das aquisições que deveriam ser feitas por meio de licitação.

Diferenciou-se da norma impugnada pela ADI 2405/RS, pois nesse caso a norma estadual foi mais sofisticada nos procedimentos a serem adotados. O bem imóvel oferecido em pagamento pelo devedor seria submetido a avaliação sobre o interesse público na aquisição, não havendo que se falar em violação do princípio da concorrência. 
Dessa forma, a norma distrital foi declarada inconstitucional pela ADI 1917/DF, não porque os entes não podem legislar sobre novas formas de extinção do crédito tributário, e sim porque o contexto normativo permitia uma burla à regra constitucional de aquisição de bens e serviços por meio de licitação.

Por fim, o mérito da ADI 2405/RS foi julgado em 2019, confirmando a inexistência de reserva de lei complementar federal para tratar de novas hipóteses de suspensão e extinção de crédito tributário. Indo além, o Ministro-relator, Alexandre de Moraes, considerou constitucional a previsão na lei estadual de extinção do crédito por dação em pagamento de bens móveis, afirmando, contudo, que este entendimento não significa superação do decidido na ADI 1917/DF.

Portanto, da análise desses julgados é possível extrair a conclusão de ser constitucional a previsão de outras formas de extinção do crédito tributário, pelos municípios, diversas daquelas previstas no CTN. Já a constitucionalidade da dação em pagamento em bens móveis ou prestação de serviços, depende da normativa formulada pelo ente municipal. Para preservar a constitucionalidade, a norma municipal deve criar uma sistemática que não viole os princípios da licitação, isonomia e concorrência.

Em um contexto de calamidade em saúde pública, como o presente, muitas das contratações de bens e serviços afetos ao combate à epidemia estão sendo feitas com base na autorização legal de dispensa de licitação, prevista no inciso IV do art. 24 da Lei n 8.666/93. Trata-se de uma situação extraordinária e imprevisível, que gera a necessidade de aquisição de novos equipamentos, materiais, profissionais, serviços em quantidades muito superiores ao que era usual até então.

Dessa forma, considerando que o princípio da licitação já é relativizado pela sistemática de dispensa do art. 24 da Lei $n^{\circ}$ 8.666/93, para situações de calamidade pública, seria justificável a previsão da dação em pagamento em bens móveis e serviços de saúde, que tenham relação direta com o combate à pandemia, como forma de extinção do crédito tributário.

Diante de um contexto em que os recursos são escassos, tanto pela queda na arrecadação, como pelo aumento nos gastos, criar uma alternativa para a aquisição de bens e serviços essenciais, sem comprometer a receita, utilizando-se de um passivo financeiro que pode nunca ser concretizado em forma de recursos públicos (dívida ativa), é uma maneira criativa e inovadora de o Poder Público municipal enfrentar a crise.

Para isso, é necessária a formulação de um procedimento legal, com critérios objetivos. A lista dos bens que podem ser adquiridos, os contribuintes/fornecedores elegíveis, os preços a serem praticados, tudo deve ser analisado e definido por meio de procedimento público, transparente, previsto em lei, com base em critérios objetivos e impessoais de julgamento e avaliação.

Poderia até se pensar na aplicação do modelo de um chamamento público aos devedores, para que mostrem o que tem a oferecer ao Poder Público, e este avalie a pertinência da dação em pagamento. 
Nesses moldes, não haveria a mencionada distorção do mercado, pois além de não haver transferência de recursos aos contratados (já que o pagamento se daria por aproveitamento do crédito público), a modalidade só se aplicaria temporariamente, de forma específica para o combate à pandemia, somente em relação aos bens e serviços diretamente relacionados a essa temática. Além disso, a excepcionalidade da situação de iminente crise de liquidez de caixa em diversos Municípios do país justificaria a eleição de fornecedores já em dívida com a Fazenda Pública.

Um exemplo prático que pode ser mencionado, é do Município do Rio de Janeiro que lançou um edital de credenciamento de estabelecimentos hoteleiros para hospedagem de idosos assintomáticos moradores de comunidades carentes visando prevenir a contaminação pelo novo Coronavírus. O artigo $1^{\circ},{ }^{\circ} 6^{\circ}$ do Decreto $n^{\circ} 47.296$ de 24 de março de 2020 , dispôs que, para os hotéis que atendam às condições do edital, o Município poderá realizar o pagamento das diárias utilizadas mediante compensação tributária, em caso de mútuo acordo, matéria a ser regulamentada por ato do Prefeito.

Da mesma forma, os entes que validamente se utilizarem do instituto excepcional da requisição administrativa de bens e serviços (artigo $5^{\circ}$, inciso $\mathrm{XXV}$, da CF), nesse momento de calamidade, poderiam utilizar a compensação tributária como forma de efetuar o pagamento de eventual indenização devida ao particular.

A compensação tributária, nesses termos, acaba sendo um instituto que atinge a mesma finalidade da dação em pagamento: obtenção de um bem ou serviço sem a necessidade de desembolso de valores por parte do ente público, que aproveita dívida já existente como forma de contraprestação.

Portanto, acredita-se que a dação em pagamento em bens móveis ou serviços não é, por definição, incompatível com o princípio da licitação. Tudo depende do arcabouço normativo que a prevê. Se forem previstos mecanismos de garantia da concorrência e da impessoalidade entre os devedores elegíveis, é possível preservar a constitucionalidade de uma medida que, apesar de restringir a isonomia entre os possíveis contratantes, garante o fornecimento de bens e serviços a Municípios com baixa liquidez de caixa.

\section{MEDIDAS ADOTADAS PELOS MUNICÍPIOS}

Muitas dessas medidas abordadas no primeiro capítulo foram efetivamente implementadas por diversos Municípios brasileiros. O presente trabalho realizou o levantamento das principais medidas adotadas pelas 26 capitais de estado brasileiras.

Segundo o IBGE, o Brasil possui 5.570 municípios. Diante dessa realidade, optou-se por uma abordagem indutiva, partindo dos municípios sede de capitais de estado, tendo em vista a sua relevância nas dinâmicas socioeconômicas locais e a maior facilidade no acesso às publicações oficiais.

Infelizmente a transparência dos atos administrativos e legislativos dos Municípios brasileiros não é muito eficiente, de forma que não é tarefa fácil encontrar a publicação oficial de decretos e leis municipais, mesmo em municípios de grande porte. 
Dos 26 municípios pesquisados, não foram encontradas medidas fiscais publicadas em seis deles (Rio Branco, João Pessoa, Teresina, Cuiabá, Campo Grande e Curitiba). Convém mencionar que o método utilizado na pesquisa foi a utilização dos termos "município" + o nome do município pesquisado + "medidas fiscais" + "pandemia", no site de pesquisa da "google", entre os dias 18 e 25 de julho de 2020.

Adotou-se como critério para exclusão desses municípios o fato de não ter aparecido nenhum resultado de notícia acerca da adoção de tais medidas na primeira página do site de pesquisa e não ter sido encontrada notícia ou legislação sobre o tema, de fácil acesso, no site oficial das respectivas prefeituras.

Nos outros vinte municípios foram encontrados leis, decretos e portarias disciplinando as medidas fiscais adotadas como resposta à crise sanitária. Após analisar cada uma dessas legislações, verificou-se que algumas medidas foram figuras repetidas no planejamento fiscal dos municípios.

A primeira delas foi o diferimento/prorrogação dos prazos de vencimento de tributos em geral (impostos, taxas e contribuições). Essa medida foi adotada por onze dos vinte municípios (Porto Velho, Boa Vista, Manaus, Macapá, Belém, Palmas, Natal, Salvador, Maceió, Vitória e Porto Alegre).

Logo após no ranking, aparece a medida de prorrogação da validade de certidões acerca da situação fiscal, certidão negativa de débito e certidão positiva com efeito de negativa, adotada por oito municípios (Porto Velho, Fortaleza, Aracaju, Recife, Maceió, Salvador, São Paulo e Rio de Janeiro).

A suspensão dos prazos de processos administrativos tributários, também foi adotada por oito dos municípios pesquisados (Goiânia, Palmas, Fortaleza, Natal, Recife Maceió, São Paulo e Rio de Janeiro).

Seis dos municípios pesquisados optaram por suspender temporariamente os atos de cobrança administrativa praticadas pelas Secretarias de Fazenda/Finança, abrangendo atos como protesto de Certidões de Dívida Ativa (CDA) e a própria inscrição em dívida. Foram os municípios de Palmas, Fortaleza, Aracaju, Maceió, Vitória e São Paulo.

É possível perceber uma relação entre a suspensão de prazos dos processos administrativos tributários e a suspensão temporária dos atos de cobrança administrativa dos tributos. Na maioria dos Municípios em que houve a suspensão dos atos de cobrança, houve também suspensão dos prazos de processos administrativos tributários.

Além disso, parte dos municípios que suspenderam a cobrança administrativa, suspenderam também o início da fase judicial da cobrança, por meio da paralisação temporária no ajuizamento das execuções fiscais. Foram eles, Aracaju, Palmas e Fortaleza.

Alguns dos municípios que previram essa suspensão temporária na cobrança administrativa dos tributos e/ou no ajuizamento das execuções fiscais, excepcionaram os atos necessários para evitar eventual prescrição e decadência dos créditos tributários, medida importante para preservar a responsabilidade fiscal da gestão municipal. Foram eles, Forta- 
leza, Aracaju, Vitória e São Paulo.

No que se refere às medidas relacionadas ao parcelamento, cinco municípios previram a possibilidade de realização de parcelamento extraordinário ou prorrogaram o prazo de adesão ao programa de regularização fiscal vigente (Manaus, Belém, São Luís, Recife e Belo Horizonte).

Além disso, alguns suspenderam os parcelamentos ativos, impedindo a rescisão do acordo pelo inadimplemento das parcelas, ou prorrogaram o prazo para pagamento das parcelas acordadas (Manaus, Macapá e Belo Horizonte).

Verifica-se, portanto, que a medida mais popular entre os municípios estudados foi o diferimento do prazo de vencimento dos tributos. De certa forma, essa preferência pela prorrogação dos prazos de vencimento era de se esperar, pois, como visto no primeiro capítulo, diferentemente da moratória, esse diferimento pode se dar por meio de ato infralegal, o que agiliza a tomada de decisão em situações de urgência.

A prorrogação da validade das certidões de situação fiscal também foi medida importante para garantir segurança jurídica aos contribuintes que se viram impossibilitados de quitar suas dívidas. Veio acompanhada, muitas vezes, das suspensões dos prazos de processos administrativos tributários e cobranças administrativas, formando um conjunto de medidas destinadas a dar fôlego aos contribuintes, possibilitando que os mesmos concentrassem seu restante de caixa no cumprimento de outras obrigações, como trabalhistas e civis.

Por fim, no que se refere aos programas de regularização fiscal, as medidas tomadas foram as já antecipadas no capítulo anterior, referentes a previsão de parcelamento extraordinário ou facilitação da adesão a parcelamento vigente, além da suspensão das rescisões de acordo pela inadimplência das parcelas, que traz as reflexões anteriormente já mencionadas.

Percebe-se, portanto, que algumas das medidas estudadas no primeiro capítulo estão sendo efetivamente adotadas pelos principais municípios brasileiros. Os ajustes na tributação local foram descritos nos atos normativos, muitas vezes, como medidas socioeconômicas, adotando-se uma postura municipal ativa na busca por auxiliar os contribuintes nesse momento de crise econômica e sanitária.

Assim, verifica-se que as medidas adotadas tem muito mais um caráter de solidariedade com os setores econômicos do que a preocupação com as contas públicas. Medidas fiscais analisadas no primeiro capítulo que poderiam ser utilizadas para manter/aumentar a arrecadação, não foram ventiladas nesse primeiro momento de reação dos municípios. Talvez, com o gradual reaquecimento da economia, a postura dos gestores mude, e a prioridade passe se concentrar mais nas medidas que visam garantir a arrecadação do que socorrer os contribuintes.

\section{CONCLUSÃO}

O presente trabalho se propôs a responder o seguinte problema: seria possível, em 
um cenário de crise econômica excepcional, como a decorrente da pandemia, manter a arrecadação municipal sem onerar o contribuinte com o aumento de carga tributária, norteada pela premissa de que, sob a perspectiva de atuação estatal anticíclica, a majoração de tributos não seria uma opção política viável.

A partir disso, verificou-se a adoção de medidas de intervenção do Estado na economia, por meio da tributação, com um caráter nitidamente extrafiscal, visando a preservação das fontes produtoras, de emprego e de renda, de interesse de toda a sociedade, já que disso depende o financiamento do próprio Estado.

Como foi possível perceber ao longo do estudo, existem alguns institutos de Direito Tributário que podem ser instrumentalizados para a otimização das contas públicas em tempos de crise econômica e sanitária. Eles se destacam, por serem alternativas de incremento da eficiência na arrecadação sem implicar o aumento da carga tributária imposta ao contribuinte

A moratória, o diferimento dos prazos de vencimentos de tributos, a suspensão das rescisões dos parcelamentos em caso de inadimplemento, são medidas que visam, primordialmente, promover um auxílio ao contribuinte, ao permitir que ele priorize, no seu balanço financeiro, outras obrigações, que não tributárias. A transação, a dação em pagamento e o parcelamento, por outro lado, são medidas que, se exploradas com essa visão instrumental e focada nas contas públicas, podem otimizar os recursos arrecadados e permitir a prestação dos serviços essenciais sem onerar ainda mais o contribuinte.

Verificou-se que, na prática, os municípios capitais de Estado, nesse primeiro momento de resposta à crise, encararam a questão fiscal como uma maneira de contribuir no auxílio dos contribuintes, na forma de "medidas socioeconômicas". A maioria das medidas não teve como foco a otimização dos recursos públicos, ou a preocupação com a arrecadação. Porém, acredita-se que essa deverá ser uma preocupação em um futuro próximo, considerando que os auxílios federais são temporários e que os efeitos da crise econômica podem perdurar por tempo indeterminado.

Quanto às repercussões sobre a responsabilidade fiscal dos gestores municipais, destacou-se que a EC no 106/2020 trouxe um regime excepcional especificamente para as medidas de combate aos efeitos econômicos da pandemia decorrente da Covid-19 e que a LC no 173/2020 alterou a LRF para dispensar a observância das condições e vedações previstas nos arts. 14, 16 e 17 da lei quando declarada calamidade pública nos termos do art. $65, \S 1^{\circ}$ da LC 101 , desde que o incentivo ou benefício "seja destinado ao combate à calamidade".

Talvez, essa flexibilização das amarras fiscais pode ter deixado os gestores mais à vontade na tomada de decisão acerca das medidas fiscais a serem adotadas. Porém, chegará o momento em que a prioridade voltará a ser a questão da arrecadação.

Assim, em conclusão, considera-se confirmada a hipótese inicialmente proposta, de que seria possível utilizar a Dívida Ativa dos municípios como fonte de recursos. A partir de um olhar mais atento às reais possibilidades econômicas do contribuinte, por meio da 
aplicação de institutos como parcelamento, moratória, transação e dação em pagamento, é possível um incremento de eficiência na arrecadação tributária, colaborando para a aproximação entre a expectativa de receita pública e a capacidade de pagamento dos devedores, sobretudo em tempos de crise econômica.

\section{NOTAS}

1. A referência entre aspas ao termo utilizado pelo legislador se deve a uma concepção crítica do modo como é tratada a repartição de receitas constitucionais no atual desenho do federalismo brasileiro: a Constituição de 1988 atribuiu aos Municípios competência para prestar diversos serviços públicos essenciais à população, mas não os dotou de rendas suficientes. Assim, enquanto a União centraliza a maior parte das receitas próprias e é responsável pela maior carga tributária suportada pelo contribuinte brasileiro, os Municípios, em sua maioria, dependem de repasses financeiros federais que, sob a ótica do federalismo cooperativo, tal como previsto no art. 23, parágrafo único da CF, não poderiam ser vistos como um "auxílio" ou outra forma de liberalidade, mas sim como uma obrigação de apoio derivada da responsabilidade conjunta de todos os entes da federação, sobretudo na área da saúde pública.

\section{REFERÊNCIAS}

ALEXANDRE, Ricardo. Direito Tributário. 11. ed. Salvador: JusPodivm, 2017.

ARACAJU. Decreto $n^{\circ} 6.112$, de 06 de abril de 2020. Dispõe sobre medidas administrativas emergenciais no âmbito fazendário, em face da pandemia de Coronavírus (COVID-19), e dá providências correlatas. Diário Oficial do Município: Aracaju, SE, 6 abr. 2020. Disponível em: https://www.legisweb.com.br/ legislacao/?id=392635. Acesso em: 27 jul. 2020.

ARAGÃO, Alexandre dos Santos. Empresas estatais: o regime jurídico das empresas públicas e sociedades de economia mista. 2. ed. Rio de Janeiro: Forense, 2018.

BELÉM. Decreto n 96.067, de 2 de abril de 2020. Institui o Programa de Regularização Incentivada PRI, com vigência de 06 a 30 de abril de 2020, e dá outras providências. Diário Oficial do Município: Belém, PA, 8 abr. 2020. Disponível em: https://www.legisweb.com.br/legislacao/?id=392802. Acesso em: 27 jul. 2020.

BELO HORIZONTE. Decreto $\mathrm{n}^{\circ} 17.308$, de 19 de março de 2020. Dispõe sobre medidas excepcionais de diferimento tributário para a redução dos impactos sobre a atividade econômica do Município causados pelas ações de contenção da pandemia ocasionada pelo COVID-19. Diário Oficial do Município: edição extra $n^{\circ}$ 5978, Ano XXVI, Belo Horizonte, MG, 19 mar. 2020. Disponível em: http://portal6.pbh.gov.br/dom/ iniciaEdicao.do?method=DetalheArtigo\&pk=1227166. Acesso em: 27 jul. 2020.

BOA VISTA. Decreto $n^{\circ} 69-E$, de 01 de julho de 2020. Altera o Decreto $n^{\circ}$ 161/E, de 26 de dezembro de 2019, que dispõe sobre o Calendário Tributário Municipal - CATRIM de 2020. Diário Oficial do Município: Boa Vista, RR, 2 jul. 2020. Disponível em: https://www.legisweb.com.br/legislacao/?id=398045. Acesso em: 27 jul. 2020.

BRANCO, Leo. Pandemia vai levar a uma onda de recuperação judicial, com até 5 mil pedidos em 2020, novo recorde. O Globo, Rio de Janeiro, 19 maio 2020. Economia. Disponível em: https://oglobo.globo. com/economia/pandemia-vai-levar-uma-onda-de-recuperacao-judicial-com-ate-5-mil-pedidos-em-2020novo-recorde-24433737. Acesso em: 11 jul. 2020. 
BRASIL. Ministério da Economia. Portaria n 247, de 16 de junho de 2020. Disciplina os critérios e procedimentos para a elaboração de proposta e de celebração de transação por adesão no contencioso tributário de relevante e disseminada controvérsia jurídica e no de pequeno valor. Diário Oficial da União: seção 1, Brasília, DF, p. 44, 17 jun. 2020. Disponível em: http://normas.receita.fazenda.gov.br/ sijut2consulta/link.action?visao=anotado\&idAto=110356\#2149833. Acesso em: 25 jul. 2020.

BRASIL. Procuradoria-Geral da Fazenda Nacional. Portaria n 14.402, de 16 de junho de 2020. Estabelece as condições para transação excepcional na cobrança da dívida ativa da União, em função dos efeitos da pandemia causada pelo coronavírus (COVID-19) na perspectiva de recebimento de créditos inscritos. Diário Oficial da União: seção 1, p. 46, 17 jun. 2020. Disponível em: http://normas.receita.fazenda.gov. br/sijut2consulta/link.action?visao=anotado\&idAto=110357. Acesso em: 25 jul. 2020.

BRASIL. Secretaria Especial de Fazenda. Comitê Gestor do Simples Nacional. Resolução no 152 de 18 de março de 2020. Diário Oficial da União: Edição extra D, 18 mar. 2020. Disponível em: http:// www.planalto.gov.br/ccivil_03/portaria/Resolucao\%20n\%C2\%BA\%20152-ME_SEF.htm. Acesso em: 17 jul. 2020.

BRASIL. Supremo Tribunal Federal. Ação Direta de Inconstitucionalidade n 1917/DF. Relator: Ministro Ricardo Lewandowski, 26 abr. 2007. Brasília. Tribunal Pleno. Diário de Justiça Eletrônico, Brasília, DF, n. 087, div. 23 ago. 2007, pub. 24 ago. 2007.

BRASIL. Supremo Tribunal Federal. Ação Direta de Inconstitucionalidade $n^{\circ}$ 2405/RS. Relator: Ministro Alexandre de Moraes, 29 set. 2019. Tribunal Pleno. Diário de Justiça Eletrônico, Brasília, DF, n. 215, div. 02 out. 2019, pub. 03 out. 2019.

BRASIL. Supremo Tribunal Federal. Medida Cautelar na Ação Direta de Inconstitucionalidade $\mathrm{n}^{\circ}$ 6357-Referendo. Relator: Min. Alexandre de Moraes, 13 de maio de 2020. Plenário. Diário de Justiça Eletrônico, Brasília, DF, n. 184, div. 02 jun. 20, pub. 03 jun. 20.

BRASIL. Supremo Tribunal Federal. Recurso Extraordinário 140.669/PE. Acórdão Republicado no DJ de 18.05.2001. Relator: Min. IImar Galvão, 2 de dezembro de 1998. Plenário. Brasília: STF, 1998. Disponível em: http://portal.stf.jus.br/processos/detalhe.asp?incidente=1522515. Acesso em: 17 jul. 2020.

BRASIL. Tribunal Superior Eleitoral. Recurso Especial Eleitoral n 79973. Relator: Min. Herman Benjamin, 02 de dezembro de 2015. Decisão monocrática. Diário da Justiça Eletrônico: Brasília, DF, p. 35-38, 9 dez. 2015.

BRASIL. Supremo Tribunal Federal. Suspensão de Segurança $n^{\circ}$ 5374. Relator: Min. Presidente Dias Toffoli, 7 de maio de 2020. Decisão monocrática. Diário da Justiça Eletrônico: Brasília, DF, n. 114, div. 08 maio 2020, pub. 11 maio 2020.

BRASIL. Tribunal Superior Eleitoral. CTA - Consulta $n^{\circ}$ 153169. Relator: Min. Marco Aurélio, 20 de setembro de 2011. Acórdão. Diário da Justiça Eletrônico: Tomo 207, p. 81, 28 out. 2011.

CARVALHO, Paulo de Barros. Curso de direito tributário. 16. ed. São Paulo: Saraiva, 2004.

DE BOLLE, Monica. O maior dos descasos. O Estado de São Paulo, São Paulo, 24 jun. 2020. Economia, p. B2. Disponível em: https://economia.estadao.com.br/noticias/geral,o-maior-dos-descasos,70003342749. Acesso em: 04 jul. 2020.

DE BOLLE, Monica. Taras. O Estado de São Paulo, São Paulo, 1 jul. 2020. Economia, p. B2. Disponível 
em: https://economia.estadao.com.br/noticias/geral,taras,70003350015. Acesso em: 4 jul. 2020.

DELOITTE. Covid-19 e os impactos nos setores econômicos: Um olhar atento às projeções Junho de 2020. [S. I.]: Deloitte, 2020. Disponível em: https://www2.deloitte.com/content/dam/Deloitte/br/Documents/ about-deloitte/Deloitte-Covid-Impacto-Setores-junho.pdf. Acesso em: 26 jul. 2020.

FLORIANÓPOLIS. Decreto $n^{\circ} 21.365$, de 25 de março de 2020. Dispõe sobre a prorrogação do vencimento das parcelas do imposto sobre serviço de qualquer natureza (ISS) fixo do ano $2020 \mathrm{em}$ decorrência da pandemia relacionada ao coronavírus (covid-19). Disponível em: http://leismunicipa.is/ phtwx. Acesso em: 27 jul. 2020.

FORTALEZA. Decreto $n^{\circ}$ 14.637, de 07 de abril de 2020. Suspende e prorroga, os prazos concernentes a atos e procedimentos de natureza tributária de competência da Secretaria Municipal de Finanças, e da Procuradoria Geral de Município de Fortaleza, na forma que indica. Disponível em: https://www.legisweb. com.br/legislacao/?id=392710. Acesso em: 27 jul. 2020.

GERBELLI, Luiz Guilherme. Com impacto do coronavírus, FMI prevê queda de 9,1\% para o PIB do Brasil neste ano. G1 Economia, [S. I.], 24 jun. 2020. Economia. Disponível em: https://g1.globo.com/ economia/noticia/2020/06/24/com-impacto-do-coronavirus-fmi-preve-queda-de-91 percent-para-o-pib-dobrasil-neste-ano.ghtml. Acesso em: 04 jul. 2020.

GOIÂNIA. Decreto n ${ }^{\circ}$ 849, de 27 de março de 2020. Dispõe sobre a suspensão de prazos administrativos no âmbito da Administração Pública Direta e Indireta do Poder Executivo do Município de Goiânia. Diário Oficial do Município Eletrônico: edição n 7268, Goiânia, GO, p. 3, 27 mar. 2020. Disponível em: https:// www.goiania.go.gov.br/wp-uploads/2020/03/Decreto-849-2020.pdf. Acesso em: 27 jul. 2020.

GUSTIN, Miracy B. S.; DIAS, Maria Tereza Fonseca. (Re) Pensando a pesquisa jurídica: teoria e prática. 2. ed. Belo Horizonte: Del Rey, 2006.

PAES, Nelson Leitão. O Parcelamento Tributário e Seus Efeitos sobre o Comportamento dos Contribuintes. Revista Economia, Brasília (DF), v. 13, n. 2, p. 345-363, maio/ago 2012. Disponível em: https://www. conjur.com.br/dl/artigo-nelson-paes-efeito-refis.pdf. Acesso em: 11 jul. 2020.

MACAPÁ. Decreto $n^{\circ} 1.972$, de 28 de abril de 2020. Dispõe sobre a prorrogação do programa de recuperação fiscal - REFIS, Lei $n^{\circ}$ 2369/2019, de 13 de novembro de 2019, e dá outras providências. Diário Oficial do Município: Macapá, AP, p. 02, 04 maio 2020. Disponível em: https://macapa.ap.gov.br/ portal/wp-content/uploads/2020/01/Di\%C3\%A1rio-Oficial-3801-04.05.2020.pdf. Acesso em: 27 jul. 2020.

MACAPÁ. Decreto $n^{\circ} 1.973$, de 28 de abril de 2020. Dispõe sobre a prorrogação dos prazos do Decreto n 009/2020-PMM. Diário Oficial do Município: Macapá, AP, p. 02-03, 04 maio 2020. Disponível em: https://macapa.ap.gov.br/portal/wp-content/uploads/2020/01/Di\%C3\%A1rio-Oficial-3801-04.05.2020.pdf. Acesso em: 27 julho 2020.

MACEIÓ. Decreto $n^{\circ} 8.910$, de 25 de junho de 2020. Dispõe sobre a postergação de medidas tributárias em face da pandemia do novo Coronavírus - (Covid-19), e dá outras providências. Diário Oficial do Município: Maceió, AL, 26 jun. 2020. Disponível em: https://www.legisweb.com.br/legislacao/?id=397587. Acesso em: 27 de jul. 2020.

MEDIDAS emergenciais no combate à Covid-19. Ações de enfrentamento à pandemia, estimadas em $\mathrm{R} \$ 370$ milhões, exigem estratégias de controle na gestão municipal. Folha de Pernambuco, [Recife], 20 jun. 2020. Disponível em: https://www.folhape.com.br/noticias/medidas-emergenciais-no-combate-a- 
covid-19/144582/. Acesso em: 27 jul. 2020.

NATAL. Secretaria Municipal da Tributação. Portaria $n^{\circ}$ 019, de 20 de março de 2020. Estabelece novas datas para recolhimento do Imposto Sobre Serviços - ISS incidente sobre a atividade exercida por Profissional Autônomo, da Taxa de Licença de Localização e da Taxa de Vigilância Sanitária. Diário Oficial do Município: Natal, RS, p. 3, 23 mar. 2020. Disponível em: https://www.natal.rn.gov.br/semut/legislacao/ portaria/portaria019_2020.pdf. Acesso em: 27 jul. 2020.

ORDEM DOS ADVOGADOS DO BRASIL. Cartilha Medidas fiscais para o combate ao coronavírus. Amazonas: OAB/AM - Comissão de Direito Tributário, 2020. Disponível em: https://oabam.org.br/ downloads/mirror/OAB_COVID-19.pdf?. Acesso em: 27 jul. 2020.

PALMAS. Decreto $n^{\circ} 1.857$, de 16 de março de 2020. Dispõe sobre a prorrogação do prazo para o pagamento do Imposto Sobre a Propriedade Predial e Territorial Urbana, da Taxa de Coleta de Lixo e da Contribuição para o Custeio do Serviço de lluminação Pública, exercício 2020. Diário Oficial do Município: Palmas, TO, 16 mar. 2020. Disponível em: https://www.legisweb.com.br/legislacao/?id=390715. Acesso em: 27 jul. 2020.

POMPERMAIER, Cleide Regina Furlani. A transação tributária e a possibilidade de se conceder desconto sobre o montante principal do débito. Revista Consultor Jurídico, São Paulo, 29 set. 2018. Disponível em: https://www.google.com.br/amp/s/ibedaft.com.br/transacao-tributaria/amp/. Acesso em: 27 jul. 2020.

PORTO ALEGRE. Decreto $\mathrm{n}^{\circ}$ 20.542, de 9 de abril de 2020. Dispõe sobre medidas para reduzir o impacto social e econômico do estado de calamidade provocado pela emergência de saúde pública de importância internacional decorrente do novo Coronavírus (COVID-19) e altera o caput do art. $9^{\circ}$ do Decreto $n^{\circ}$ 20.325, de 6 de agosto de 2019. Disponível em: http://dopaonlineupload.procempa.com.br/ dopaonlineupload/3323_ce_287215_1.pdf. Acesso em: 27 jul. 2020.

PORTO VELHO. Decreto $n^{\circ} 16.613$, de 25 de março de 2020. Dispõe sobre as medidas para enfrentamento dos efeitos econômicos decorrentes da pandemia causada pelo novo Coronavírus (COVID-19) no Município de Porto Velho. Diário Oficial do Município: Porto Velho, RO, 26 mar. 2020. Disponível em: https://www.legisweb.com.br/legislacao/?id=391729. Acesso em: 27 jul. 2020.

RECIFE. Decreto $n^{\circ} 33.549$, de 20 de março de 2020. Dispõe sobre medidas emergenciais no âmbito fazendário em face da pandemia do novo Coronavírus (Covid-19), e dá outras providências. Diário Oficial do Município: Recife, PE, 21 mar. 2020. Disponível em: https://www.legisweb.com.br/ legislacao/?id=391330. Acesso em: 27 jul. 2020.

RECIFE. Lei $n^{\circ} \mathbf{1 8 . 7 0 1}$, de 30 de março de 2020. Prorroga o prazo para adesão Programa de Parcelamento Incentivado (PPI) previsto na Lei no 18.650, de 30 de outubro de 2019, em razão de Estado de Emergência decorrente da Pandemia do COVID-19 (coronavírus). Diário Oficial do Município: Recife, PE, 31 mar. 2020. Disponível em: https://www.legisweb.com.br/legislacao/?id=391993. Acesso em: 27 jul. 2020.

RIO DE JANEIRO (Município). Decreto $n^{\circ} 47.264$, de 17 de março de 2020. Dispõe sobre medidas emergenciais no âmbito fazendário em face da pandemia do novo Coronavírus - Covid-19, e dá outras providências. Diário Oficial do Município: Ano XXXIV, Rio de Janeiro, RJ, p. 3, 18 mar. 2020. Disponível em: https://pge.rj.gov.br/comum/code/MostrarArquivo.php?C=MTA0Njg\%2C. Acesso em: 27 jul. 2020.

RIO DE JANEIRO (Município). Decreto n 47.296, de 24 de março de 2020. Dispõe sobre o procedimento para credenciamento de estabelecimentos hoteleiros para hospedagem de idosos assintomáticos 
moradores de comunidades carentes visando prevenir a contaminação pelo novo Coronavírus - COVID-19 - e dá outras providências. Diário Oficial do Município: Ano XXXIV, nº 8, Rio de Janeiro, RJ, p. 2, 24 mar. 2020. Disponível em: https://pge.rj.gov.br/comum/code/MostrarArquivo.php?C=MTA0NzY\%2C. Acesso em: 27 jul. 2020.

RIO DE JANEIRO (Estado). Decreto estadual nº 45.692 de 17 de junho de 2016. Decreta estado de calamidade pública, no âmbito da Administração Financeira do Estado do Rio de Janeiro e dá outras providências. Diário Oficial do Estado do Rio de Janeiro: $\mathrm{n}^{\circ}$ 110-A, 17 jun. 2016. Disponível em: http:// www.silep.planejamento.rj.gov.br/decreto_45_692_-_17062016_-_de.htm. Acesso em: 26 jul. 2020.

SALVADOR. Decreto $n^{\circ} 32.576$, de 13 de julho de 2020. Prorroga, em caráter excepcional, o prazo de vigência dos efeitos das Certidões Negativas emitidas pela Secretaria Municipal da Fazenda e da condição de contribuinte adimplente, e dá outras providências. Diário Oficial do Município: Salvador, BA, 14 jul. 2020. Disponível em: https://www.legisweb.com.br/legislacao/?id=398529. Acesso em: 27 jul. 2020.

SÃO LUÍS. Decreto ${ }^{\circ} 55.102$, de 13 de maio de 2020. Dispõe sobre a prorrogação de prazos de validade de certidões de regularidade fiscal no âmbito do município de São Luís, como medida temporária, devido à pandemia mundial causada pelo coronavírus (Covid-19). Disponível em: https://www.semfaz.saoluis. ma.gov.br/lista_arquivos?/0/2/0/0/1. Acesso em: 27 jul. 2020.

SÃO LUÍS. Decreto $n^{\circ}$ 55.164, de 01 de junho de 2020. Regulamenta a Lei $n^{\circ} 6.597$ de 18 de dezembro de 2019, estipulando regras, condições e datas de vencimentos para pagamento do Imposto Sobre a Propriedade Predial e Territorial Urbana - IPTU, para o exercício de 2020 e dá outras providências. Disponível em: https://www.semfaz.saoluis.ma.gov.br/lista_arquivos?/0/2/0/0/1. Acesso em: 27 jul. 2020.

SÃO LUíS. Decreto $n^{\circ} \mathbf{5 5 . 2 2 1}$, de 17 de junho de 2020. Dispõe sobre a regulamentação da Lei Municipal $n^{\circ}$ 6.794/2020, definido prazos, condições e documentos para adesão ao Programa Especial de Recuperação de Créditos da Fazenda Municipal de São Luís - REFAZ, instituído como medida temporária, devido à pandemia mundial causada pelo Coronavírus (COVID-19). Disponível em: https:// www.semfaz.saoluis.ma.gov.br/lista_arquivos?/0/2/0/0/1. Acesso em: 27 jun. 2020.

SÃO PAULO (Município). Decreto $n^{\circ}$ 59.326, de 2 de abril de 2020. Estabelece medidas para redução do impacto social e econômico decorrente das providências de restrição adotadas para o enfrentamento da pandemia ocasionada pelo coronavírus. Diário Oficial da Cidade: São Paulo, SP, p. 1, 3 abr. 2020. Disponível em: http://legislacao.prefeitura.sp.gov.br/leis/decreto-59326-de-2-de-abril-de-2020. Acesso em: 27 jul. 2020.

SCAF, Fernando Facury. Refis é uma transação tributária e não uma renúncia fiscal. Revista Consultor Jurídico, São Paulo, 2 dez. 2014. Disponível em: https://www.conjur.com.br/2014-dez-02/contas-vistarefis-transacao-tributaria-nao-renuncia-fiscal. Acesso em: 27 jul. 2020.

SCHREIBER, Anderson. Manual de Direito Civil Contemporâneo. São Paulo: Saraiva Educação, 2018.

SENADO FEDERAL. Orçamento público municipal: as fontes de receita. Jornal Em Discussão, Brasília, DF. Disponível em: https://www.senado.gov.br/noticias/Jornal/emdiscussao/contas-publicas/realidadebrasileira/orcamento-publico-municipal-as-fontes-de-receita.aspx. Acesso em: 5 jul. 2020.

TORRES, Ricardo Lobo. Curso de Direito Financeiro e Tributário. 18. ed. Rio de Janeiro: Renovar, 2011. 
TRIBUNAL DE CONTAS DO ESTADO DE SANTA CATARINA. Consulta. Decisão 501/2020, processo $n^{\circ}$ 17/00707865. Ata n. 14/2020. Possibilidade transação do principal, juros e multa de crédito tributário, e configuração de renúncia de receita. Relator: Luiz Eduardo Cherem, Sessão virtual, 24 jun. 2020. Disponível em: http://servicos.tce.sc.gov.br/processo/visualizador.php?cddoc=MTcwMDcwNzg2NQ==. Acesso em: 28 jul. 2020.

VITÓRIA. Decreto $n^{\circ} 18.051$, de 25 de março de 2020. Altera o Decreto $n^{\circ} 17.963$, de 23 de dezembro de 2019, que estabelece o Calendário Fiscal do exercício de 2020 e dá outras providências e dá outras providências. Diário Oficial do Município: Vitória, ES, 26 mar. 2020. Disponível em: https://www. legisweb.com.br/legislacao/?id=391738. Acesso em: 27 jul. 2020.

VITÓRIA. Decreto $n^{\circ} 18.064$ de 2 de abril de 2020. Declara estado de calamidade pública no Município de Vitória para enfrentamento da pandemia da COVID-19 e dá outras providências. Diário Oficial do Município: Vitória, ES, 7 abr. 2020. Disponível em: https://www.legisweb.com.br/legislacao/?id=392627. Acesso em: 27 jul. 2020.

WAISBERG, Ivo; SACRAMONE, Marcelo Barbosa; NUNES, Marcelo Guedes, CORRÊA, Fernando. Recuperação Judicial no Estado de São Paulo $-2^{\text {a }}$ Fase do Observatório de Insolvência. Disponível em: https://abj.org.br/wp-content/uploads/2019/04/Recuperacao_Judicial_no_Estado_de_Sao_Pa.pdf. Acesso em: 11 jul. 2020.

Recebido em: 03/08/2020

Aceito em: 19/08/2020 